\title{
ASSUMPTIONS ON SOCIAL SUCCESS AND MOTIVATION IN YOUTHFUL AGE
}

\author{
Olga Kobzeva \\ Murmansk Arctic State University, Russian Federation \\ Olga Tuzova \\ Murmansk Arctic State University, Russian Federation
}

\begin{abstract}
The problem of social success has not been considered as an independent one in Psychology for a long time, but it has been included in the structure of research related to effective communication, social status and professional competence. The increased interest in it is due to the growing attention to the problem of personality changes, an increase in the environmental "challenges" to human abilities, as well as the need to quickly respond to changes in society. The authors study the role of social success in the structure of mental development of the personality; define the determinants that affect its formation and development. The purpose of research is to study the correlation between the level of motivation for success and assumptions on social success among youthful age. The study involved 258 respondents (99 young men and 159 young ladies aged 18 to 21 years). The researchers used a psychodiagnostic method, including two techniques (the "Successful person" method by G.R. Khuzeeva, the method of diagnosing motivation for success by T. Ehlers, in adaptation of E.P. Belinskaya), methods of mathematical and statistical analysis, a genetic method. The results of the study showed that the assumptions on social success in youthful age is associated with getting education, self-confidence, determination, hard work. The authors revealed the relationship between the learners' level of motivation for success and their assumptions on social success. In a group of young men with a high level of motivation for success, assumptions on social success are associated with the activity aspect (diligence, one's own activity, responsibility) and the humanistic orientation (well-disposed, responsive, able to sacrifice). Respondents with a low level of motivation for success have a material orientation in the image of success (careerist, entrepreneurial, has connections with the right people).
\end{abstract}

Keywords: motivation, social success, transitive society, VUCA world, youthful age.

\section{Introduction}

The sociocultural transformations taking place in modern society affect all spheres of everyday life: information environment, communication system, social attitudes, moral values, etc. These transformations not only change the standard of socialization, but also determine the emergence of new interests and needs within society (Martsinkovskaya \& Poleva, 2017). 
The transitivity of modern society is manifested in uncertainty, multidimensionality, as well as the lack of authority and low predictability of social changes. The changed landscape of modern times puts forward new requirements not only to society, but also to each individual. At the same time, the personality is a source of versatility, variability, as well as any innovation in society.

The situation of transitivity is especially acute in youthful age, when there is awareness of one's own individuality, deep moral restructuring, life goals and a stable image of oneself are formed. The social space in this age period not only develops social systems and relationships, but also determines the well-being of the individual (Kobzeva, 2019).

Social success is one of the most important values in the modern transitive society. It acts as an indicator of the individual's social status (Petrusevich \& Satov, 2019), stimulates a person's inclusion in the system of social ties and relations (Kozhakina, 2016). Social intelligence can be considered the criterion of social success or failure. It allows one to control reactions to decisions and optimistically assess difficult situations (Goleman, 2000).

Despite the increased interest in the problem of social success, nevertheless, an unequivocal position regarding its semantic definition, structural components and criteria to diagnose it have not yet been formed in psychology.

A special role in the formation of social success belongs to motivation. Its quality (Ryan \& Deci, 2002), as well as the relationship of the set up or accepted goal with the personality (Leontiev, 2016) as a whole deserve close attention. The transitivity of society contributes to the fact that a person can demonstrate unexpected behavioral responses to tested stimuli, and the mismatch of stimuli and reactions will reduce one's adaptability in society.

Thus, an important point in the study of personal development in a situation of uncertainty will be an analysis of the dependence of ideas about social success on the level of motivation for success in youthful age.

\section{Literature review}

The modern VUCA world combines the fast-paced dynamics of changes and their changeable nature, the growth of uncertainty, the diminishing capabilities of the forecasted world and the events taking place in it, the increasing complexity of social and technical structures, the increasing multiplicity of influencing factors and the ambiguity of the world. Man's attempts to avoid a new reality will lead to his maladaptation and isolation. Adequate response to ongoing changes will not only preserve mental health, but also help fulfill oneself and form patterns of socially successful behavior. Therefore, an adequate picture of oneself, one's 
place, one's role in different social groups is formed only through interaction with society.

The increased interest in studying the phenomenon of social success is due to the new environment that has globally changed the world, the search for new, effective motivators for personal development in conditions of the variability and uncertainty of society. In Russian psychology, aspects of social success associated with hardiness and mental health of an individual (Ajvarova, Mironov, \& Naumova, 2018), intellectual giftedness (Yurkevich, 2018), and hemispheric asymmetry are considered (Zaitueva, 2017).

In foreign psychology, social success is studied from the standpoint of practical orientation. The dominant role in its formation and development belongs to self-esteem (Boudreau \& Boswell, 2001; Sutin, Costa, Miech, \& Eaton, 2009) and the external attractiveness of a person (Agthe, Sporrie, \& Forsterling, 2008). At the same time, hypertrophied motivation for financial success has a negative impact on the feeling of psychological well-being, satisfaction with one's own life, and social success (Nickerson, Schwarz, Diener, \& Kahneman, 2003). Therefore, the essential aspect of motivation is the person's attitude to perceived reality. It is the motivational sphere that prompts the action, the formation of the activity goal (Quinton \& Brunton, 2017), the process of choosing between different actions.

The motive of achievement allows the individual to do something quickly and well, to reach a certain level in any business. Therefore, there is a constant analysis of the goals of the activity, a return to something previously abandoned. A person motivated for success is very persistent in achieving his goals. Motivation for achievement is an important factor in the society's productivity (McClelland, 2009). Success is not only the result itself, but the assessment, the substantive basis of the personality's motivational sphere.

\section{Methodology}

This empirical study is a small part of the research project devoted to the study of the problem of social success in the transitive society.

The purpose of the study was to identify the characteristics of ideas about social success among young people with different levels of motivation to achieve success.

The researchers suggested that people with different levels of motivation for success have different ideas about social success: high motivation for success determines the activity aspect, and low motivation for success is associated with material orientation and group affiliation in ideas about social success.

The research paradigm determined the choice of methods and techniques, as well as the design of the study. A psychodiagnostic method, methods of 
mathematical and statistical data analysis and a genetic method were used in the work.

The study was conducted with the psychodiagnostic method at Murmansk Arctic State University (MASU). The participants were 258 respondents (99 young men and 159 young ladies aged from 18 to 21 years). The average age of the respondents was 19,8. The study was conducted with the voluntary consent of the participants. To achieve greater sincerity, diagnostics was performed anonymously. Interested persons were provided with the results of the study.

The study used standardized and validated psychodiagnostic methods. Ideas about social success were studied using the "Successful Person" (Khuzeeva, 2015) methodology, which allows us to differentiate the substantial characteristics of success according to indicators such as the activity aspect, humanistic focus, material orientation and group affiliation. "Diagnostics of motivation for success" methodology was used for the diagnosis of motivation (Belinskaya, 2016). It determines the extent of motivation to achieve success in the professional sphere among the respondents.

Statistical evaluation of the results of the study was performed using the Fisher $\varphi$-test.

\section{Results and Discussion}

The analysis of empirical data by the "Successful Person" method made it possible to single out the main definitions that were put in first place by the respondents. It should be noted that when describing the image of a successful person, girls give more descriptions, so the ideal image is more structured and differentiated. Table 1 presents the characteristics of a successful person.

Table 1 Characteristics of a successful person according to opinions of the young people (\%)

\begin{tabular}{|c|l|c|c|c|}
\hline \multirow{2}{*}{} & \multirow{2}{*}{$\begin{array}{c}\text { characteristics of a successful } \\
\text { person }\end{array}$} & \multicolumn{3}{|c|}{ number of selections } \\
\cline { 3 - 5 } & & young men & young ladies & total \\
\hline 1 & purposeful & 28,3 & 21,5 & 24 \\
\hline 2 & smart, educated & 22,2 & 11,3 & 15,5 \\
\hline 3 & rich, having rich parents & 36,3 & 0 & 14 \\
\hline 4 & brave, confident & 0 & 14,5 & 9 \\
\hline 5 & hardworking & 0 & 11,3 & 7 \\
\hline 6 & sociable & 7,1 & 5,7 & 6 \\
\hline 7 & independent & 7,1 & 3,1 & 4,6 \\
\hline
\end{tabular}

As the results of the study show, the dominant characteristic of a successful person in youthful age is determination. This is due to the fact that the current 
situation of development, development tasks, declare the need for an active life position, encourage respondents to use all their potential abilities for selfrealization and personal growth within the framework of those social conditions and the culture in which they develop. To a greater extent, this definition is characteristic of young ladies. Young men put material values in the first place. This position is formed by the requirements of modern society towards men (material support for all family members, to be financially generous in relations).

Important components of social success for young ladies are confidence, education and hard work. Modern multidimensional culture involves "liquid" socialization, in which a multidimensional and non-directed impact is possible, and the result can be delayed, latent. One of the options for such a delayed result is a change in standards of behavior, so the increasing spread of standards of masculinity is characteristic not only for young men, but also for young ladies.

Young men consider a purposeful and educated person successful. The interiorization of the external requirements of society allows them to navigate in the system of social roles that currently exists in society, as well as fulfill their potential successfully. It is self-realization that requires social acceptance, as a measure of social success. Therefore, in any situation, you must win in order to be noticed, build a career and, as a result, become successful.

Thus, the determinants of social success in youthful age are personal qualities (determination, confidence, industriousness, sociability), wealth and education.

The results of the study of ideas about social success of students made it possible to analyze such substantial characteristics of a successful person as an activity component, a humanistic and material orientation (table 2).

Table 2 Results of studying ideas about social success in youthful age (\%)

\begin{tabular}{|c|c|c|c|}
\hline \multirow{2}{*}{$\begin{array}{c}\text { indicators of ideas about } \\
\text { social success }\end{array}$} & \multicolumn{3}{|c|}{ characteristics of success in description } \\
\cline { 2 - 4 } & $\begin{array}{c}\text { not present in } \\
\text { description }\end{array}$ & $\begin{array}{c}\text { present in } \\
\text { description }\end{array}$ & $\begin{array}{c}\text { predominant in } \\
\text { description }\end{array}$ \\
\hline activity aspect & 10 & 30 & 60 \\
\hline humanistic orientation & 10 & 50 & 40 \\
\hline material orientation & 60 & 30 & 10 \\
\hline group affiliation & 50 & 40 & 10 \\
\hline
\end{tabular}

The results presented in the table indicate that the largest number of the respondents (60\%) gives characteristics of a successful person, which can be attributed to the activity aspect. When describing a successful person, such words as "purposeful”, "hardworking”, "active”, “confident”, “courageous”, "professional”, "educated" were used most of all. 
The second place is occupied by the characteristics of a successful person, which determine his humanistic orientation. These include such definitions as sociability, communicability, the ability to manage, help people, etc. Material orientation and group affiliation are presented to a lesser extent in the youth. Here we can say that when describing a successful person the largest percentage of the respondents (60\%) does not use definitions associated with material values, such as money, wealthy parents, an apartment, a car, etc.

At the next stage of the study, various levels of motivation to achieve success were identified with the use of the "Diagnostics of Successful Motivation" methodology (table 3).

Table 3 Successful motivation in youthful age (\%)

\begin{tabular}{|c|c|c|c|c|}
\hline \multirow{2}{*}{ respondents } & \multicolumn{4}{|c|}{ level of motivation for success } \\
\cline { 2 - 5 } & low & medium & moderately high & high \\
\hline young men & 9,1 & 48,5 & 32,3 & 10,1 \\
\hline young ladies & 10,7 & 59,1 & 12,6 & 17,6 \\
\hline total & 10 & 55 & 20 & 15 \\
\hline
\end{tabular}

The table shows that medium level of motivation for success in youthful age is predominate. For this reason respondents are passive in achieving the goal. To a greater extent, this trend is characteristic of young men $(\varphi$ emp. $=1.66 ; p<0.1)$. Young ladies are more focused on achieving their goals. They are active, proactive, plan their future for the long term, choose achievable goals. That's why they more fully realize their abilities and more often achieve their goals $(\varphi$ emp. $=$ $1.7 ; \mathrm{p}<0.1)$. It should be noted that positive relationship between success, selfesteem and confidence more characterized for young men ( $\varphi$ emp. $=3.76 ; \mathrm{p}<0.01)$.

Based on the results obtained, 4 groups of respondents were formed (table 4).

Table 4 Comparative analysis of ideas about social success among groups with different levels of motivation for success (\%)

\begin{tabular}{|c|c|c|c|c|}
\hline \multirow{2}{*}{$\begin{array}{l}\text { indicators of the } \\
\text { successful } \\
\text { person's image }\end{array}$} & \multicolumn{4}{|c|}{ groups of respondents according to the level of motivation for success } \\
\hline & $\begin{array}{c}\text { group } 1 \\
\text { (with a low } \\
\text { level, } 26 \text { pp.) }\end{array}$ & $\begin{array}{c}\text { group } 2 \\
\text { (with a medium } \\
\text { level, } 142 \text { pp.) }\end{array}$ & $\begin{array}{c}\text { group } 3 \\
\text { (with a } \\
\text { moderately high } \\
\text { level, } 52 \text { pp.) }\end{array}$ & $\begin{array}{c}\text { group } 4 \\
\text { (with a high } \\
\text { level, } 38 \text { pp.) }\end{array}$ \\
\hline activity aspect & 10 & 40 & 70 & 80 \\
\hline $\begin{array}{l}\text { humanistic } \\
\text { orientation }\end{array}$ & 10 & 30 & 20 & 20 \\
\hline $\begin{array}{c}\text { material } \\
\text { orientation }\end{array}$ & 60 & 20 & 0 & 0 \\
\hline group affiliation & 20 & 10 & 10 & 0 \\
\hline
\end{tabular}


The presented results suggest that descriptive characteristics associated with material orientation prevail in the group with a low level of success motivation (a car, a house, an yacht, rich); no significant differences in the dominance of any indicator of success were found in the group with a medium level of motivation for success; and the characteristics of a successful person that relate to the activity aspect prevail in groups with a moderately high and very high level of motivation for success (hardworking, receptiveness, inquisitiveness). The validity of differences in ideas about social success between groups with different levels of motivation for success is significant $(\varphi$ emp. $=2.75 ; \mathrm{p}<0.002 ; \varphi$ emp. $=3.13$; $\mathrm{p}<0.0001 ; \varphi$ emp. $=6.123 ; \mathrm{p}<0.0001)$.

\section{Conclusions}

The analysis of modern research and the conducted empirical research allows us to formulate a number of conclusions. The phenomenon of social success requires clarification and further study in the context of global socio-economic and other changes with the prospect of creating a model of a socially successful person in the transitive society. It is possible to determine to what extent a person is socially successful only in case of his interaction with society.

A study of social success in youthful age showed that most respondents believe that success is the result of their own activity. Persistence and high intellectual abilities are the main definitions of social success from the point of view of young men. Sociability and independence determine success in society to a lesser extent, in their opinion.

In the descriptions of social success, the activity aspect prevails, which indicates the synonymy of the definition of a successful and creative person. Therefore, social success is a resource of human actions, allowing one to form the variables necessary for socialization: obligations and expectations, information channels and social norms.

The motivation for success is a necessary determinant of the competitive personality formation in conditions of globalization. Own activity, industriousness, ability to defend one's interests, mobility, education, that is personal resources of a person, contribute to success in activities. The orientation to material values in youthful age is interconnected with high readiness to risk and low motivation for achievements in the professional sphere.

The study showed the versatility of the social success phenomenon, allowed to expand knowledge of value orientations in adolescence, highlight success definitions in conditions of transitivity and uncertainty. 
Kobzeva \& Tuzova, 2020. Assumptions on Social Success and Motivation in Youthful Age

\section{References}

Agthe, M., Sporrie, M., \& Forsterling, F. (2008). Success Attributions and More: Multidimensional Extensions of the Sexual Attribution Bias to Failure Attributions, Social Emotions, and the Desire for Social Interaction. Personality and Social Psychology Bulletin, 34(12), 1627-1638. DOI: 10.1177/0146167208324446.

Ajvarova, N.G., Mironov, A.V., \& Naumova, M.V. (2018). Zhiznestojkost' i psihologicheskoe zdorov'e molodezhi korennyh malochislennyh narodov severa. Psihologija obrazovanija $v$ polikul'turnom prostranstve, 41(1), 6-12.

Belinskaya, E.P. (2016). Metodika diagnostiki motivacii k uspehu. Iz T.D. Martsinkovskaya, E.M. Duboskaya, E.P. Belinskaya, \& N.A. Golubeva (red.), Socializacija $v$ mul'tikul'turnom prostranstve (pp. 41-43). Moskva: Moskovskij pedagogicheskij gosudarstvennyj universitet.

Boudreau, J.W., \& Boswell, W.R. (2001). Effect of personality on executive career success in the United States and Europe. Journal of Vocational Behavior, 58(1), 53-81. DOI: 10.1006/jvbe.2000.1755.

Goleman, D. (2000). Working with Emotional Intelligence. London: Bantam.

Khuzeeva, G.R. (2015). Metodika uspeshnyj chelovek. In T.D. Martsinkovskaya (red.), Identichnost' i socializacija $v$ sovremennom mire (pp. 11-13). Moskva: Moskovskij pedagogicheskij gosudarstvennyj universitet.

Kobzeva, O.V. (2019). Hardiness and coping behavior in youthful age. Retrieved from https://www.futureacademy.org.uk/files/images/upload/PSYRGGU2019F032.pdf DOI: 10.15405/epsbs.2019.07.32

Kozhakina, S.O. (2016). Formirovanie social'noj uspeshnosti podrostkov v obrazovatel'noj srede. Nauchnoe obozrenie: gumanitarnye issledovanija, 3, 67-78.

Leontiev, D.A. (2016). Samoreguljacija, resursy i lichnostnyj potencial. Sibirskiy psikhologicheskiy zhurnal, 62, 18-37. DOI: 10.17223/17267080/62/3.

Martsinkovskaya, T.D., \& Poleva, N.S. (2017). Pokolenija jepohi tranzitivnosti: cennosti, identichnost', obshhenie. Mir psihologii, 1(89), 24-37.

McClelland, D.C. (2009). Human Motivation. Cambridge: Cambridge University Press.

Nickerson, C., Schwarz, N., Diener, E., \& Kahneman, D. (2003). Zeroing in the dark side of American dream: A closer look at the consequences of the goal for financial success. Psychological Science, 14(6), 531-536. DOI: 10.1046/j.0956-7976.2003.psci_1461.x.

Petrusevich, A.A., \& Satov, M.K. (2019). Pedagogicheskaja podderzhka kak sredstvo formirovanija pozicii social'noj uspeshnosti kursantov voennogo vuza. Vestnik Omskogo gosudarstvennogo pedagogicheskogo universiteta. Gumanitarnye issledovanija, 1(22), 120-123.

Ryan, R.M., \& Deci, E.L. (2002). Overview of self-determination theory: an organismic dialectical perspective. In E.L. Deci, R.M. Ryan (Eds.), Handbook of self-determination research (pp. 3-33). Rochester: The University of Rochester Press.

St. Quinton, T., \& Brunton, J.A. (2017). Implicit Processes, Self-Regulation and Interventions for Behavior Change. Frontiers in Psychology, 8. Retrieved from https://www.frontiersin.org/articles/10.3389/fpsyg.2017.00346/full DOI: 10.3389/fgsyg.2017.00346

Sutin, A.R., Costa, P.T., Miech, R., \& Eaton, W.W. (2009). Personality and Career Success: Concurrent and Longitudinal Relations. European journal of personality, 23(2), 71-84. 
Yurkevich, V.S. (2018). Intellektual'naja odarennost' i social'noe razvitie: protivorechivaja svjaz'. Sovremennaja zarubezhnaja psihologija, 7(2), 28-38. Retrieved from https://psyjournals.ru/files/93914/jmfp_2018_n_2_Yurkevich.pdf

DOI: $10.17759 / j m f p .2018070203$

Zaitueva, S.U. (2017). Mezhpolusharnaja asimmetrija i social'naja uspeshnost'. Iz V. Sokhranov (red.), Psihologo-pedagogicheskie aspekty razvitija sovremennogo obrazovanija $v$ Rossii (pp. 110-114). Penza: Avtonomnaja nekommercheskaja nauchno-obrazovatel'naja organizacija Privolzhskij dom Znanij. 